\title{
Legal Analysis Of Giving Remission To Fostered Citizens Of Criminal Acts In Narcotics In The Narcotics Special Class Ila Gintung Cirebon
}

\begin{abstract}
Suhada ${ }^{1}$ and Aryani Witasari ${ }^{2}$
Abstract. The problems of this study are: 1) How can the application of remissions the inmates of narcotics cases in the Penitentiary (Prison) Narcoticts Class IIA Gintung Cirebon? 2) Are the obstacles in granting remission to the prisoners in the prisons of narcotics cases Narcotics Class IIA Gintung Cirebon?

The method used is a sociological juridical approach. Specifications research used in this research is descriptive analysis. The sources and types of data in this study are primary data and secondary data.

Based on the results of this study concluded that Application of remissions the inmates of narcotics cases in the Penitentiary (Prison) Narcoticts Class IIA Gintung Cirebon tightened after the enactment Government Regulation No. 99 Of 2012 and the Regulation of the Minister of Law and Human Rights No. 3 of 2018. Constraints in granting remission to the prisoners in the prisons of narcotics cases Narcotics Class IIA Gintung Cirebon because in addition to the provisions stipulated by Government Regulation No. 99 Of 2012 and the Regulation of the Minister of Law and Human Rights No. 3 of 2018, also the following provisions: a) Punishable with a penalty of less than 6 months; b) Disciplinary penalties and violations are listed at the register book prisons or detention order within the time period taken into account in granting remission; c) Leave ahead of undergoing free; d) Sentenced to imprisonment substitute fines.

Keywords: Legal Analysis; Remission; Citizens Patronage of Corrections; Crime; Narcotics
\end{abstract}

\section{Introduction}

One manifestation of transnational crime is crucial for the future of generations of a nation, especially among the younger generation of this country is a crime in the field of drug abuse. Narcotics syndicates operating mode with ease, can penetrate the boundaries of countries in the world through a network of neat management and advanced technology and into Indonesia as a transit country or the destination country even as illegal drug trafficking ${ }^{3}$, Problems that arise in narcotic crime that has great language, it is their ambiguous in terms of setting remissions for prisoners Narcotics, that there is a difference when compared with WBP general crime, for WBP Narcotics there are special requirements that make it difficult to get a remission, so WPB Narcotics Prison of Gintung Cirebon, often protesting the injustice and discrimination of this remission.

In development terms with the abuse of drugs known as narcotics, psychotropic and / or dangerous drugs, as well as other terms of drug which is a description of narcotics,

\footnotetext{
${ }^{1}$ Student of Master of Law, Universitas Islam Sultan Agung Semarang and Police Member, email: shd6667@gmail.com

${ }^{2}$ Lecturer of Master of Law, Sultan Agung Islamic University (UNISSULA), Semarang

3 I Nyoman Nurjana, penanggulangankejahatannarkotika: eksekusihakperspektif sociology of law, ejournal.umm, accessed December 5, 2017, http: // Ejournal. umm.ac.id/index. php / legality / article / view / 306
} 
psychotropic and addictive substances. However this is not an issue in this writing. Drugs and Drug Abuse in Indonesia is a very worrying problem for the younger generation of damage in the future.

Likewise, in the Correctional (prisons) that confine the convicted narcotics massif occurred precisely, so that the public requires the evaluation of the coaching system at the Institute of prisons. Various events are concerned, the brawl between prisoners at Rutan Salemba ${ }^{4}$. Fighting between inmates in prison Class IIB Mojokerto ${ }^{5}$, Fighting between inmates in prisons Class I Kesambi Cirebon ${ }^{6}$, Fighting between inmates in prisons Class I Tanjung Gusta Medan ${ }^{7}$ Prisoner narcotic self-immolation in Cipinang Narcotics Prison ${ }^{8}$, Inmates fight to his stomach wound in Prison Class IIA Denpasar ${ }^{9}$ More surprising by the former Head of Sub BNN Sr. Slamet Pribadi that 70 percent of drug trafficking in Indonesia is controlled by the inmates of the Correctional especially prisoners sentenced to death, but did not immediately executed ${ }^{10}$, Drug Investigation Division Cilacap dismantle drug trafficking in Narcotics Prison Class II A reclaiming and confiscated $\mathbf{1 5 6 . 5}$ grams of methamphetamine, a digital scale pieces, seven mobile phone unit from the Pak Cik/Zainal Abidin, sentenced to death, Bambang Poncho Karno Popong aka death row $^{11}$, BNN catch initials AA and warden initials DR in Prison Class II A Karawang in West Java and confiscated 16.3 kilograms of methamphetamine and 778 grains of Inex (ecstasy). ${ }^{12}$

Based on the exposure of the background of the problem as described above, then the problem under study is formulated as follows: How the application of remissions the inmates of narcotics cases in the Penitentiary (Prison) Narcoticts Class IIA Gintung Cirebon?; Do obstacle in granting remission to the prisoners in the prisons of narcotics cases Narcotics Class IIA Gintung Cirebon?

\section{Research methods}

In this study, the method used is a sociological juridical approach. Juridical sociological (socio-legal approach) intended to study and examine the reciprocal relationship in real terms associated with social variables other. specification of research used in this research is descriptive analysis, the research aimed to obtain a clear and systematic about the circumstances or the facts of the problems studied as something intact ${ }^{13}$

\section{Results and Discussion}

\subsection{Granting the application of Remission Residents Patronage on Narcotic Cases In}

\footnotetext{
${ }^{4}$ See m.tempo.com occurred on Friday, September 20th, 2013.

${ }^{5}$ See the brawl incident m.detik.com week of August 23, 2015.

${ }^{6}$ See Tribunnews.com brawl occurred on Sunday, January 20, 2013 date.

${ }^{7}$ See VIVA.co.id, occurred Friday, April 26, 2013.

${ }^{8}$ See m.liputan6.com Tuesday, November 24, 2015.

${ }^{9}$ See bali.tribunnews.com.

${ }^{10}$ See nasional.kompas.com, Thursday, December 12, 2013.

${ }^{11}$ See www. antarajateng.com Monday, August 19, 2013.

${ }^{12}$ See m.elshinta.com May 24, 2015.

${ }^{13}$ Fajar Mukti ND, Et al, 2010, Dualisme Penelitian Hukum Normatif dan Empiris, Yogyakarta: Pustaka Pelajar, p. 192.
} 


\section{Penitentiary (Prison) Narcotics Class IIA Gintung Cirebon}

Correctional mean a return to society become good citizens and good for society. Further highlight the correctional system development and not vengeance, so that the convict can understand and realize his mistake, so once returned to the community will not repeat the unlawful deed back. Therefore Sahardjo as the originator of the prison has since 1963 suggests that the violation of the law is no longer referred to as a criminal but as a person who lost ${ }^{14}$,

According to RA Koesnoen, imprisonment is a criminal revocation of independence, and the words of the prison comes from the word "penjoro" (Java) which means "repentance", while "imprisoned" meaning "made into repentance" ${ }^{15}$, At the beginning of the implementation of the penal system, Sahardjo as the originator of Prisons has put forward some constraints in the implementation of the replacement of the prison into the prison, namely: (a) change the prison in accordance with the ideals of correctional require substantial costs; (B) correctional officers are still few who understand the purpose of prison; (C) a cost issue; and (d) the people who still have not received the prisoners after being released from prison ${ }^{16}$, In line with that Mochtar Kusumaatmadja found the correctional system has not become a system that is rounded and integrated, because it is not supported by the four primary means, means of legislation, suggestions personnel, facilities and infrastructure finance the institution itself ${ }^{17}$,

Convicted of narcotics and precursors of narcotics, psychotropic substances, which are entitled to remission, but must meet the requirements specified in Article 34 above, it must also meet the requirements specified in Article 34A, namely: is willing to cooperate with law enforcement to help dismantle the criminal case he does; The willingness requirement applies only to inmates who shall be punished with imprisonment of at least five (5) years. Willingness to work as intended should be stated in writing and set out by law enforcement agencies in accordance with the provisions of the legislation.

Narcotics Prison Class II A Gintung Central Gintung located in the village, district. Ciwaringin District Cirebon is a special prison holds convicted of narcotics. The Narcotics Prison inhabitants already overcapacity (beyond capacity), in addition to be placed in prisons Narcotics of Gintung, narcotics convict was scattered in various prisons in Region III Cirebon. Provisions that restrict remissions of prisoners of narcotics, in addition to impede drug development program, also causes Narcotics Prison of Gintung be crowded, because every time got a shipment of prisoners / convicts narcotics while spending limited because one of them a limitation by the

\footnotetext{
${ }^{14}$ Romli Atmasasmita, 1982, Strategi Pembinaan Pelanggar Hukum Dalam Konteks Penegakan Hukum Di Indonesia, Bandung: Alumni, p. 12.

${ }^{15}$ R. Achmad S. Soemadipradja and Romli Atmasasmita (Ed.), Tt, Sistem Pemasyarakatan Di Indonesia, Bandung: BPHN Departemen Kehakiman Binacipta, p. 17.

${ }^{16}$ Soedjono Diredjosisworo, 1984, Sejarah Dan Azas-azas Penologi (Pemasyarakatan), Bandung: Armico, p. 185.

${ }^{17}$ Romli Atmasasmita, op.cit., P. 15-22.
} 
provision of remission ${ }^{18}$ complicated for prisoners narcotics.

In each remissions either on Independence Day Celebration Homeland and Big Day Religious, inmates in prisons Class II A Narcotics of Gintung and prisons more constantly alert and heightened security and safety, especially in anticipation of inmates narcotic that do not get a remission, lest disappointment inmate narcotics that are not receive remission is expressed into the fray on the inside, and not impossible also will seek a stir with inmates get remission in order to equally receive remission $^{19}$,

Application of remissions the inmates of narcotics cases in the Penitentiary (Prison) Narcoticts Class IIA Gintung Cirebon tightened after the enactment Government Regulation No. 99 Of 2012 and the Regulation of the Minister of Law and Human Rights No. 3 of 2018.

\subsection{Constraints In Remission Giving Citizens Patronage In Case Narcotics Inside Narcotics Prison Class IIA Gintung Cirebon}

Remission nomination procedure shall be submitted to the Ministry of Justice by the Head of the Penitentiary, the Head of State or Head of the Detention Branch State Prison through the Head Office of the Ministry of Law and Human Rights. Minister of Justice and Human Rights of remission notified to the Prisoners and Criminal Kids on the anniversary of the Proclamation of Independence of the Republic of Indonesia on August 17 for those who are granted remission on the anniversary of Indonesian Independence Proclamation or on religious holidays embraced by the Child Prisoners and Criminal concerned. If there was any doubt about the religious holidays or Child Prisoners adopted by the Code, the Minister of Law and Legislation consult with the Minister of Religious Affairs.

Correctional system is a system that not only rehabilitation, but equipped with educational elements, correlative, definitive, and individual and social in Ideology based on Pancasila. The system itself within the correctional must have a size or other conditions, certain elements that the interrelation and proceed in accordance with a certain conception.

Problem Child Prisoners and Criminal coaching historically always changing. Over the centuries, its existence is widely disputed by experts. When listened to from the point of the development of society, the change is something that is fair, because people will always endeavor to update on a case in order to improve their welfare by basing itself on its past experience.

In connection with remissions for prisoners and drug criminal child as stipulated in Government Regulation No. 32 of 1999 on the Terms and Procedures for Citizens Rights Patronage of Corrections (hereinafter Regulation No. 32 of 1999), amended by the first Government Regulation No. 28 of 2006 (the next PP No. 28 of 2006) and the Government Regulation No. 99 Of 2012 (hereinafter Regulation No. 99 of 2012), then that provision is seen as a tightening one remissions for prisoners Drugs.

\footnotetext{
${ }^{18}$ According to information from Herry Purnomo, SH., MH., Narcotics Prison officers Gintung Cirebon. based on the results of the interview on December 5, 2019.

${ }^{19}$ Results of interviews with Cepy Mulyawan, A.Md.IP., SH., MH. Narcotics Prison officers Gintung Cirebon, based on the interview on December 5, 2019 at 13:35 pm
} 
In connection with the development of inmates in correctional institutions, lately frequent riots penitentiary. One was the riots in Banceuy Bandung Correctional Institution, according to the Ministry of Justice stated Yasonna Hamonangan Laoly ${ }^{20}$ : "That the PP was a source of unrest LP Banceuy 23 April 2016. He was lighter fury prisoners, especially in the case of drugs, because they hope to be faster to be blocked. PP 99/2012 is tightening remissions for convicted drug, also to convict corruption and terrorism. "

Penal system that applied the Indonesian nation is transformed into the correctional system have changed the paradigm that the prison became a place of torture into place in order to realize the inmates coaching mistakes and not repeat the criminal act so that to be fully human. Citizens become Patronage of Corrections (WBP) who realized the mistake, fix, and not to repeat the criminal act that can be received by the community, can actively participate in the development and can be normal life as a good citizen and responsible ${ }^{21}$,

Changes penal system into the correctional system is perceived inmates at the Correctional (prisons) and State Prison (Rutan) who is currently serving a criminal. One perceived reduction in criminal past inmates are set forth in the Penal Law that inmates are entitled to a reduction in criminal past (remission) ${ }^{22}$,

Constraints in granting remission to the prisoners in the prisons of narcotics cases Narcotics Class IIA Gintung Cirebon because in addition to the provisions stipulated by Government Regulation No. 99 Of 2012 and the Regulation of the Minister of Law and Human Rights No. 3 of 2018, also the following provisions: ${ }^{23}$

- Shall be sentenced to less than 6 months;

- Disciplinary penalties and violations are listed at the register book prisons or detention order within the time period taken into account in granting remission;

- Leave ahead of undergoing free;

- Sentenced to imprisonment substitute fines.

\section{Closing}

\subsection{Conclusion}

- Application of remissions the inmates of narcotics cases in the Penitentiary (Prison) Narcoticts Class IIA Gintung Cirebon tightened after the enactment Government Regulation No. 99 Of 2012 and the Regulation of the Minister of Law and Human Rights No. 3 of 2018.

- Constraints in granting remission to the prisoners in the prisons of narcotics cases Narcotics Class IIA Gintung Cirebon because in addition to the provisions stipulated by Government Regulation No. 99 Of 2012 and the Regulation of the Minister of

\footnotetext{
20 Media Indonesia, "Maintaining Remission tightening," htp: //mediaindonesia.com/editorials/ detail_editorials / 726-, accessed August 23, 2018.

${ }^{21}$ Indonesia, Act No. 12 of 1995 on Penal, Article 1 (2) 5 lbid, Article 14 paragraph (1) poit i.

22 Indonesia, Government Regulation No. 32 of 1999 on the Terms and Procedures for Correctional Patronage Citizen Rights, Article 1 (6).

${ }^{23}$ Results of interviews with Cepy Mulyawan, A.Md.IP., SH., MH. Narcotics Prison officers Gintung Cirebon, based on the interview on December 5, 2019 at 13:35 pm
} 
Law and Human Rights No. 3 of 2018, also the following provisions: ${ }^{24}$ Shall be sentenced to less than 6 months; Disciplinary penalties and violations are listed at the register book prisons or detention order within the time period taken into account in granting remission; Leave ahead of undergoing free; Sentenced to imprisonment substitute fines.

\subsection{Suggestion}

- Applying different requirements for prisoners certain crimes to get remission, should the provisions of difference terms are set forth in the legislation, because under Article 28J paragraph (2) of the Constitution of 1945 every person shall be subjected to restrictions on human rights set forth by law OF to ensure recognition and respect for the rights and freedoms of others.

- Reducing overcapacity that occurs in prisons, remissions to convicted drug could be a solution for the problems of overcapacity that occurs in prisons at this time because of the number of prisoners narcotic approximately $50.87 \%$ of the total number of occupants prisons. However, the policy does not apply to dealers and producers of drugs, should equalization condition of granting remission to prisoners narcotics inmates are generally effective only for users, because of imprisonment for drug users proved unable to deal with the problem of addiction pathway by drug users.

\section{References}

[1] I Nyoman Nurjana, penanggulangankejahatannarkotika: eksekusihakperspektif sociology of law, ejournal.umm, accessed December 5, 2017, http: // Ejournal. umm.ac.id/index. php / legality / article / view / 306

[2] Indonesia, Government Regulation No. 32 of 1999 on the Terms and Procedures for Correctional Patronage Citizen Rights, Article 1 (6).

[3] Indonesia, Act No. 12 of 1995 on Penal

[4] Media Indonesia, "Maintaining Remission tightening," htp: //mediaindonesia.com/editorials/ detail_editorials / 726-, accessed August 23, 2018.

[5] Fajar Mukti ND., Et al, 2010, Dualisme Penelitian Hukum Normatif dan Empiris, Yogyakarta: Pustaka Pelajar

[6] R. Achmad S. Soemadipradja and Romli Atmasasmita (Ed.), Tt, Sistem Pemasyarakatan Di Indonesia, Bandung: BPHN Departemen Kehakiman Binacipta

[7] Romli Atmasasmita, 1982, Strategi Pembinaan Pelanggar Hukum Dalam Konteks Penegakan Hukum Di Indonesia, Bandung: Alumni

[8] Soedjono Diredjosisworo, 1984, Sejarah Dan Azas-azas Penologi (Pemasyarakatan), Bandung: Armico

\footnotetext{
${ }^{24}$ Results of interviews with Cepy Mulyawan, A.Md.IP., SH., MH. Narcotics Prison officers Gintung Cirebon, based on the interview on December 5, 2019 at 13:35 pm
} 